\title{
FAKTOR-FAKTOR PRODUKSI YANG MEMPENGARUHI PENDAPATAN PENGERAJIN PADA INDUSTRI KERAJINAN KULIT DI KABUPATEN BADUNG
}

\author{
I Gede Ari Bona Tungga Dangin ${ }^{1}$ \\ A.A.I.N. Marhaeni \\ 1,2Jurusan Ekonomi Pembangunan Fakultas Ekonomi dan Bisnis Unversitas \\ Udayana (Unud), Bali, Indonesia \\ e-mail: tunggadangin@gmail.com
}

\begin{abstract}
ABSTRAK
Penelitian ini bertujuan 1) untuk menganalisis pengaruh tenaga kerja, modal, teknologi dan ketersediaan bahan baku terhadap jumlah produksi, 2) menganalisis pengaruh tenaga kerja, modal, teknologi, ketersediaan bahan baku, dan produksi terhadap pendapatan dan 3) untuk menganalisis pengaruh tidak langsung tenaga kerja, modal, teknologi, dan ketersediaan bahan baku terhadap pendapatan melalui produksi pada pengerajin pada industri kerajinan kulit di Kabupaten Badung. Sampel dalam penelitian ini sebanyak 62 pengerajin. Teknik analisis data yang digunakan adalah analisis jalur. Hasil analisis menujukkan tenaga kerja dan modal berpengaruh positif dan signifikan terhadap produksi pengerajin pada industri kerajinan kulit. Penggunaan teknologi modern menghasilkan produksi yang lebih tinggi daripada teknologi tradisional dan ketersediaan bahan baku yang lancar menghasilkan produksi yang lebih tinggi daripada yang tidak lancar. Tenaga kerja, modal dan produksi berpengaruh positif dan signifikan terhadap pendapatan pengerajin pada industri kerajinan kulit. Penggunaan teknologi modern menghasilkan pendapatan yang lebih tinggi daripada teknologi tradisional dan ketersediaan bahan baku yang lancar menghasilkan pendapatan yang lebih tinggi daripada yang kurang lancar. Produksi memediasi secara parsial pengaruh tenaga kerja modal, teknologi dan ketersediaan bahan baku terhadap pendapatan pengerajin pada industri kerajinan kulit.
\end{abstract}

Kata kunci: tenaga kerja, modal, teknologi, bahan baku, produksi, pendapatan

\begin{abstract}
The aims at this study are 1) to analyze the effect of labor, capital, technology and availability of raw materials on production, 2) the influence of labor, capital, technology, availability of raw materials and production on income and 3) the indirect influence of labor, capital, technology and availability of raw materials on income through the production of craftsmen in the leather craft industry. Sample size of this used is about 62 craftsmen in the leather craft. The results show that labor and capital have a positive and significant effect on the production of craftsmen in the leather craft. The firm that use modern technology has higher production than the firm that use traditional technology. The availability of smooth raw materials results in higher production than the substandard ones. Labor, capital and production have a positive and significant effect on the income of craftsmen in the leather craft industry. Using of modern technology generates higher income than traditional technology. The availability of raw materials that smoothly generates higher income than those that have less smooth. Production mediates partially the influence of labor capital, technology and availability of raw materials on the income of craftsmen in the leather craft industry.
\end{abstract}

Keywords: labor, capital, technology, raw materials, production, income 


\section{PENDAHULUAN}

Industri kecil dan menengah merupakan salah satu pendorong pertumbuhan ekonomi, yang menyebabkan kenaikan pendapatan total dan pendapatan perkapita (Allo, 2017). Sektor industri memegang peran kunci sebagai mesin pembangunan karena sektor industri memiliki beberapa keunggulan dibandingkan sektor lain karena nilai kapitalisasi modal yang tertanam sangat besar, kemampuan menyerap tenaga kerja yang besar, juga kemampuan menciptakan nilai tambah (value added creation) dari setiap input atau bahan dasar yan diolah. Sektor industri juga memiliki peranan yang besar dalam mempercepat pertumbuhan ekonomi di suatu negara.

Pertumbuhan ekonomi dapat memperlancar proses pembangunan ekonomi (Artana Yasa, 2015). Industri kecil dan menengah telah mendapatkan perhatian lebih karena pertumbuhannya yang semakin pesat karena kinerja Industri Kecil Menengah (IKM) sangat efisien, produktif dan memiliki tingkat daya saing global yang tinggi. Industri memiliki peranan yang sangat penting bagi masyarakat sebagai mata pencahrian untuk mencukupi kekurangan pendapatan kelurga (Istanti, 2016). Kegiatan sektor ini juga berperan aktif dalam menunjang perkembangan Produk Domestik Bruto, kesempatan kerja dan pendapatan rumah tangga. Hal ini karena produk-produk sektor industri memiliki nilai tukar yang lebih menguntungkan dan menciptakan nilai tambah yang lebih tinggi.

Sektor industri mempunyai variasi produk yang beragam dibandingkan dengan produk sektor lainnya (Agyapong, 2010). Selain itu, sektor industri tidak tergantung pada keadaan alam seperti musim dan curah hujan, maka pelaku bisnis 
lebih memanfaatkan sektor industri (Idayanti, 2015). Keberadaan sektor ini sangat mendukung percepatan pembangunan perekonomian di suatu daerah dan dapat mengatasi permasalahan ekonomi yang bersifat multidimensi seperti pengangguran (Juan, 2008). Eksistensi dari sektor ini akan semakin berkembaang apabila didukung oleh keberadaan sektor pariwisata. Hal ini karena daerah yang menjadi pusat pariwisata akan memiliki akses pasar yang lebih luas dalam memasarkan hasil produksinya, yang berpeluang meningkatkan efisiensi perusahaan. Salah satu daerah yang potensial dalam pengembangan sektor industri dan kerajinan rumah tangga adalah Provinsi Bali.

Provinsi Bali merupakan salah satu daerah tujuan wisatawan baik lokal, nusantara ataupun mancanegara. Provinsi Bali merupakan salah satu daerah yang potensial bagi tumbuh kembang sektor industri dan kerajinan rumah tangga. Pembangunan industri kerajinan di Bali saat ini sudah berkembang dengan pesat, bahkan untuk beberapa komoditas telah diekspor ke berbagai negara di dunia (Idayanti, 2015). Pengembaangan industri kerajinan yang ada di Provinsi Bali dipandang sebagai upaya yang strategis dan mengingat usaha ini sangat beranekaragam yang sesuai dengan potensi daerah. Jumlah industri dan kerajinan rumah tangga sangat banyak dan beranekaragam, salah satunya komoditi kerajinan kulit.

Kerajinan kulit merupakan suatu karya dari pemanfaatan kulit yang keberadaannya tidak terlepas dari pengaruh modernisasi salah satunya transformasi pariwisata. Perkembangan kerajinan kulit di Bali dilihat dari aspek bentuk, jenis, maupun maknanya bagi masyarakat. Kerajinan ini memperlihatkan 
bentuk dan jenisnya yang sangat beragam dengan makna ekonomis, sosial dan budaya. Adapun jenis-jenis kerajinan kulit adalah sepatu, tas, dompet, ikat pinggang, jaket, aksesoris dan masih banyak lagi yang lainnya. Bagi sebagian orang, kerajinan kulit atau barang dari kulit merupakan hal yang wajib dimiliki. Hal ini dikarenakan barang dari kulit memiliki kesan klasik dan formal yang tidak bisa digantikan bahan tekstil. Data Badan Pusat Statistik menujukkan bahwa Bali merupakan salah satu provinsi di Indonesia yang menjadi penghasil dan mengekspor cukup banyak kerajinan kulit. Berikut ini sepuluh besar komoditas ekspor kerajinan di Provinsi Bali yitu ditunjukan pada Tabel 1.

Tabel 1.

Sepuluh Besar Komoditas Ekspor Kerajinan di Provinsi Bali Tahun 2010-2014 (dalam Rupiah)

\begin{tabular}{clrrrrr}
\hline No & Komoditi Ekspor & \multicolumn{1}{c}{$\mathbf{2 0 1 0}$} & $\mathbf{2 0 1 1}$ & $\mathbf{2 0 1 2}$ & $\mathbf{2 0 1 3}$ & \multicolumn{1}{c}{$\mathbf{2 0 1 4}$} \\
\hline 1 & Kerajinan Kayu & 77.805 .653 & 63.341 .444 & 71.493 .260 & 90.618 .137 & 73.243 .287 \\
2 & Kerajinan Furniture & 30.635 .943 & 30.804 .932 & 34.818 .965 & 28.175 .524 & 34.715 .939 \\
3 & Kerajinan Perak & 26.748 .603 & 27.288 .653 & 21.968 .434 & 23.738 .340 & 22.566 .727 \\
4 & Kerajinan Bambu & 9.542 .874 & 10.475 .545 & 12.864 .022 & 9.486 .097 & 18.335 .991 \\
5 & Kerajinan Logam & 11.914 .775 & 11.652 .365 & 9.741 .524 & 11.228 .568 & 15.211 .828 \\
6 & Kerajinan Terracota & 7.201 .117 & 4.020 .457 & 3.410 .240 & 2.334 .873 & 2.566 .727 \\
7 & Kerajinan Kulit & 9.901 .719 & 8.484 .569 & 9.705 .384 & 9.236 .328 & 9.541 .913 \\
8 & Kerajinan Batu & 18.506 .462 & 15.359 .503 & 11.484 .690 & 10.265 .244 & 14.772 .477 \\
& Padas & & & & & \\
9 & Kerajinan Anyaman & 1.535 .987 & 2.448 .140 & 2.085 .820 & 1.062 .490 & 3.643 .201 \\
10 & Kerajinan Keramik & 1.346 .419 & 1.910 .242 & 1.053 .703 & 1.478 .951 & 1.660 .458 \\
\hline
\end{tabular}

Sumber: Desprindag Provinsi Bali, 2016

Berdasarkan Tabel 1 selama lima tahun terakhir (2010-2014) kerajinan kulit menjadi salah satu dari sepuluh besar komoditas ekspor dan turut memberi kontribusi terhadap total nilai ekspor Provinsi Bali. Nilai ekspor kerajinan kulit selama periode 2010-2014 cukup stabil, meskipun sempat mengalami penurunan pada tahun 2011 yaitu menurun sebesar 14,01 persen dari tahun sebelumnya, hal ini diindikasikan terjadi karena penurunana permintaan konsumen. Pada tahun 
2012-2014 jumlah permintaan kembali meningkat. Hal tersebut dinilai dapat menggambarkan bahwa pasar kerajinan kulit di Bali sangat menjanjikan dan berpotensi untuk dikembangkan lebih serius.

Industri kerajinan kulit di Provinsi Bali berkembang di beberapa kabupaten/kota seperti di Badung, Gianyar, Tabanan, Buleleng, dan Denpasar. Meskipun demikian, pariwisata di Bali hingga saat ini masih terpusat di Kabupaten Badung dengan berbagai tempat wisata dan akomodasi yang sudah tersedia, kesempatan untuk memperluas pasar produk hasil kerajinan kulit di Kabupaten Badung sangat besar. Hal itu dikarenakan didukung oleh posisi Kabupaten Badung sebagai gerbang utama Bali yang sudah pasti banyak dilalui wisatawan, baik domestik maupun asing, oleh karena itu penelitian ini akan mengambil lokasi penelitian di Kabupaten Badung. Berikut mengenai produksi kerajinan keramik di Provinsi Bali per Kabupaten serta faktor-faktor produksi yang digunakan dalam produksinya di tunjukkan pada Tabel 2.

Tabel 2.

Jumlah Bahan Baku, Tenaga Kerja dan Nilai Produksi Industri Kerajinan Kulit di Kabupaten Badung Tahun 2012-2015

\begin{tabular}{ccccc}
\hline Tahun & $\begin{array}{c}\text { Nilai } \\
\text { (Ribu Rupiah) }\end{array}$ & $\begin{array}{c}\text { Bahan } \\
\text { Raku }\end{array}$ & Tenaga Kerja (orang) & $\begin{array}{l}\text { Nilai Produksi (Ribu } \\
\text { Rupiah) }\end{array}$ \\
\hline 2012 & 932.833 & 74 & 1.630 .072 \\
2013 & 1.292 .833 & 87 & 2.380 .081 \\
2014 & 2.265 .893 & 105 & 3.837 .672 \\
2015 & 3.609 .233 & 155 & 4.223 .253 \\
\hline
\end{tabular}

Sumber: Disperindag Provinsi Bali, 2016 (Data Diolah)

Tabel 2 menunjukkan bahwa nilai bahan baku, jumlah tenaga kerja, dan nilai produksi pada industri kerajinan kulit di Kabupaten Badung sepanjang tahun 2012 hingga 2015 terus mengalami peningkatan. Hal ini menujukkan bahwa terjadi peningkatan terhadap permintaan kerajinan kulit yang berasal dari industri 
kerajinan kulit di Kabupaten Badung di pasaran. Peningkatan ini diharapkan mampu memberikan dampak positif bagi perolehan pendapatan pengerajin pada industri kerajinan kulit di Kabupaten Badung.

Dalam upaya untuk memenuhi permintaan terhadap kerajinan kulit maka akan sangat dipengaruhi oleh tingkat produksi yang mampu dihasilkan oleh pengerajin. Perbedaan tingkat produksi yang dihasilkan oleh para pengerajin akan memicu terjadinya kesenjangan pendapatan. Keberadaan akses modal yang terbatas yang menjadi salah satu kendala dalam mencapai tingkat produktivitas yang maksimal (Parinduri, 2016). Pendapatan merupakan keseluruhan penerimaan yang diterima pekerja, rumah tangga atau pedagang, baik berupa fisik maupun non fisik selama bekerja atau berusaha (Kurniawan, 2016).

Tingkat produksi akan mempengaruhi tingkat pendapatan yang diperoleh oleh pengerajin pada industri kerajinan kulit. Ketika produksi yang dihasilkan menurun maka pendapatan yang diterima pengerajin akan mengalami penurunan. Temuan Limi (2013), menunjukkan bahwa terdapat hubungan yang positif antara jumlah produksi terhadap pendapatan. Penelitian dari Catherine (2012) dan Godby (2015), yang menyatakan bahwa tingkat produksi akan berbanding lurus dengan tingkat pendapatan yang diperoleh seseorang. Artinya, semakin tinggi jumlah produksi yang dihasilkan maka akan semakin tinggi pendapatan yang diperoleh.

Keberadaan kerajinan kulit di Kabupaten Badung merupakan salah satu alternatif dalam menanggulangi peningkatan pengangguran dan merupakan sumber pendapatan bagi para pengerajin. Aktivitas ekonomi yang semakin meningkat akan menyebabkan semakin tingginya persaingan antar pelaku industri 
dalam memperoleh pendapatan. Perbedaan perolehan pendapatan tersebut akan memicu terjadinya kesenjangan pendapatan dan ketidakefisienan perkembangan industri terkait. Pendapatan adalah salah satu alat yang sangat penting dalam pemenuhan kebutuhan sehari-hari. Semakin banyak pendapatan yang diperoleh, semakin terpenuhi kebutuhan yang diinginkan. Terpenuhinya kebutuhan yang diinginkan oleh seseorang membuat dirinya semakin dekat untuk mencapai kesejahteraan (Hae-Yang, 2013). Besar kecilnya pendapatan yang diperoleh akan mempengaruhi skala usaha dan tingkat kesejahteraan masyarakat (Hurt, 1971).

Kesejahteraan merupakan suatu hal yang bersifat subjektif sehingga setiap orang mempunyai pandangan hidup, tujuan hidup, dan cara hidup berbeda-beda (Todaro, 2006). Kesejahteraan diukur berdasarkan indikator-indikator, yaitu dari sudut pandang ekonomi, kesehatan dan sosial. Setiap orang akan berusaha untuk meningkatkan kesejahteraannya dan kemakmuran hidupnya. Kesejahteraan masyarakat di suatu daerah dilihat dari nilai IPM. Semakin baik nilai IPM suatu daerah kabupaten/ kota maka rata-rata semakin tinggi tingkat kesejahteraan masyarakat di daerah tersebut. Salah satu upaya untuk meningkatkan kesejahteraan adalah melalui perolehan pendapatan.

Tenaga kerja merupakan faktor penting yang mempengaruhi pendapatan. Tenaga kerja merupakan faktor penggerak faktor input yang lain, tanpa adanya tenaga kerja maka faktor produksi lain tidak akan berarti. Meningkatnya produktifitas tenaga kerja akan mendorong peningkatan produksi sehingga pendapatan pun akan ikut meningkat (Prastyo, 2017). Penggunaan tenaga kerja mampu meningkatkan pendapatan melalui peningkatan jumlah produksi yang 
dihasilkan. Tenaga kerja memiliki hubungan yang positif dan signifikan terhadap pendapatan (Pieere, 2009). Hasil penelitian ini juga didukung oleh Yuniartini (2013) yang menyatakan bahwa tenaga kerja berpengaruh positif dan signifikan terhadap pendapatan. Pernyataan ini semakin diperkuat oleh hasil penelitian yang dilakukan, Asmie (2008) dan Ginting (2008) menyebutkan bahwa tenaga kerja mempengaruhi tingkat pendapatan.

Peningkatan kualitas tenaga kerja melalui pendidikan informal dan formal dapat meningkatkan produksi pada industri tersebut dan akhirnya berdampak pula terhadap peningkatan pendapatan. Tujuan manajemen tenaga kerja adalah untuk mengoptimalkan pelaksanaan kerja karena adanya berbagai batasan yang melingkupi operasi organisasi (Woo, 2015). Keinginan sesorang untuk terjun ke dunia kerja dipengaruhi oleh tingkat pendapatan yang diperoleh yang diukur dari tingkat upah atau gaji yang diterima. Berikut ini adalah perkembangan UMK selama lima tahun di Kabupaten Badung yang di tunjukkan pada Tabel 3.

Tabel 3.

Perkembangan UMK di Kabupaten Badung Tahun 2013-2017

\begin{tabular}{cc}
\hline Tahun & UMK (Rupiah) \\
\hline 2013 & 1.401 .000 \\
2014 & 1.728 .000 \\
2015 & 1.905 .000 \\
2016 & 2.124 .075 \\
2017 & 2.299 .311 \\
\hline
\end{tabular}

Sumber: www.gajimu.com, 2018

Berdasarkan Tabel 3 dapat diketahui bahwa selama 5 tahun terakhir (20132017) tingkat UMK di Kota Denpasar terus mengalami peningkatan. Melihat tingkat UMK yang terus meningkat maka diharapkan hal yang sama juga terjadi pada industri kerajinan kulit. Hal ini terjadi karena pemberian upah, salah satunya 
perlu memperhatikan nili UMK selain produktivitas yang dihasilkan sebagai tolak ukur produksi.

Faktor yang juga mempengaruhi pendapatan pengerajin kulit di Kabupaten Badung adalah modal usaha. Modal yang digunakan oleh pengerajin kulit di Kabupaten Badung berasal dari modal yang mereka keluarkan sendiri, namun beberapa diantara mereka yang tidak memiliki cukup modal untuk memulai usahanya akan melakukan pinjaman di lembaga keuangan bank ataupun non bank. Suatu usaha akan membutuhkan modal secara terus-menerus untuk mengembangkan usaha yang menjadi penghubung alat, bahan dan jasa yang digunakan dalam produksi untuk memperoleh hasil penjualan (Putri, 2017). Ariessi (2017), menyatakan bahwa faktor modal memberikan pengaruh terhadap pendapatan, karena ketersediaan modal akan memaksimalkan skala usahanya. Modal merupakan semua bentuk kekayaan yang dapat digunakan langsung maupun tidak langsung dalam proses produksi untuk menambah output (Revathy, 2016).

Teknologi adalah faktor lain yang mempengaruhi proses produksi dan tingkat pendapatan pada industri kecil dan menengah. Teknologi sebagai suatu alat bantu dapat dimanfaatkan dalam proses produksi, sehingga upaya untuk meningkatkan penjualan dapat secara maksimal dilakukan dan pendapatan usaha akan mengalami peningkatan. Bantuan teknologi berupa mesin dapat mempercepat dan memudahkan proses produksi yang dilakukan. Menurut Mutiara (2010) bahan baku mempunyai pengaruh paling tinggi terhadap produksi, karena 
apabila bahan baku sulit didapatkan maka produsen akan menghentikan produksi. Bahan baku berpengaruh signifikan terhadap produksi (Ningsih, 2015).

Jumlah bahan baku yang meningkat dan didukung dengan jumlah mesin berbantuan teknologi yang canggih, maka jumlah pendapatan yang diperoleh akan meningkat. Jadi, ketika jumlah bahan baku meningkat dan dalam produksinya didukung oleh pemanfaatan teknologi berupa mesin yang memadai akan mendorong peningkatan jumlah output dan pendapatan usaha. Peningkatan jumlah output yang diperoleh akan berdampak terhadap jumlah pendapatan yang diperoleh juga akan meningkat (Reiner Kummel, 2002).

Dari sisi usaha pengembangan produk-produk industri lokal dan dari segi penyerapan tenaga kerja itu sejalan dengan pertumbuhan ekonomi. Terjadinya ketimpangan pendapatan antar pengerajin pada industri kerajinan kulit di kabupaten Badung dapat dipicu dari adanya persaingan dan perbedaan strategi pasar dalam upaya produksi dan penjulan. Ketimpangan yang terjadi dapat dilihat dari skala usaha dari masing-masing pengerajin. Strategi yang perlu dikembangkan dalam bidang produksinya adalah dengan mengetahui faktor-faktor yang mempengaruhi produksi seperti penggunaan tenaga kerja, menekan harga bahan baku, menekan biaya operasional, modal, jam kerja, teknonolgi dan lain sebagainya.

Berdasarkan uraian tersebut, tujuan dari penelitian ini adalah sebagai berikut 1) untuk menganalisis pengaruh tenaga kerja, modal, teknologi dan ketersediaan bahan baku terhadap produksi pengerajin pada industri kerajinan kulit di Kabupaten Badung, 2) untuk menganalisis pengaruh tenaga kerja, modal, 
teknologi, ketersediaan bahan baku dan produksi terhadap pendapatan pengerajin pada industri kerajinan kulit di Kabupaten Badung, 3) untuk menganalisis pengaruh tidak langsung tenaga kerja, modal, teknologi dan ketersediaan bahan baku terhadap pendapatan melalui produksi pengerajin pada industri kerajinan kulit di Kabupaten Badung.

\section{METODE PENELITIAN}

Penelitian ini menggunakn pendekatan kuantitatif yang berbentuk asosiatif kausalitas. Penelitian ini dilakukan untuk mengkaji pengaruh tenaga kerja, modal, teknologi dan ketersediaan bahan baku terhadap pendapatan dengan menggunakan produksi sebagai variabel intervening. Penelitian ini dilakukan di Kabupaten Badung. Hal ini dilakukan karena Kabupaten Badung merupakan salah satu daerah yang terdapat di Provinsi Bali yang memiliki potensi pasar yang baik dalam industri perkembangan kerajinan kulit.

Variabel endogen adalah variabel yang hanya berfungsi sebagai variabel terikat dimana dalam penelitian ini adalah pendapatan pengerajin pada industri kerajinan kulit di Kabupaten Badung. Pendapatan merupakan pendapatan pengerajin pada industri kerajinan kulit di Kabupaten Badung yang dicerminkan dengan penerimaan yang diperoleh pengerajin setelah dikurangi dengan biaya produksi. Satuan dari pendapatan yang adalah dalam satuan rupiah. Variabel intervening dalam penelitian ini adalah poduksi kerajinan kulit di Kabupaten Badung. Produksi merupakan nilai produksi kerajinan berbahan kulit yang 
dihasilkan oleh pengerajin pada industri kerajian kulit di kabupaten Badung dalam jangka waktu 1 bulan, yang dinyatakan dalam satuan rupiah.

Variabel eksogen dalam penelitian ini adalah tenaga kerja, modal, teknologi dan ketersediaan bahan baku. Tenaga kerja mencerminkan jumlah tenaga kerja yang dipakai dalam usaha pada industri kerajinan dari kulit selama satu bulan. Variabel ini diukur dengan menggunakan satuan orang. Modal merupakan jumlah uang yang dikeluarkan oleh pengrajin kulit untuk membeli bahan kerajinan dan untuk biaya operasional, dengan satuan rupiah per bulan. Teknologi mencerminkan teknologi yang dipakai dalam usaha pada industri kerajinan dari kulit di Kabupaten Badung. Teknologi menggunakan variabel dummy, dimana $1=$ untuk yang mennggunakan teknologi modern, dan $0=$ untuk yang mennggunakan teknologi tradisional. Ketersediaan Bahan baku mencerminkan kelancaran ketersediaan bahan baku yang dipakai dalam proses pembuatan kerajinan kulit pada industri kerjinan kulit di Kabupaten Badung. Ketersediaan bahan baku diukur menggunakan dummy, dimana 1 = lancar, dan 0 $=$ tidak lancar.

Jenis data yang digunakan dalam penelitian ini adalah data kuantitatif yang diperoleh dari hasil penyebaran kuisioner mengenai tenaga kerja, modal, teknologi, ketersediaan bahan baku, produksi dan pendapatan pengerajin pada industri kerajinan kulit di Kabupaten Badung. Sumber data yang digunakan adalah data primer, yaitu data yang secara langsung bersumber dari responden dan didukung oleh data sekunder yang diperoleh melalui media perantara dan dalam bentuk tidak jadi. 
Populasi dalam penelitian ini adalah pengerajin kerajinan kulit di Kabupaen Badung sebanyak 155 orang. Metode yang digunakan untuk menentukan sampel yaitu teknik proportionate stratified random sampling, yaitu adalah cara yang diambil karena anggota bersifat tidak homogen. Dengan menggunakan rumus Slovin, populasi sebanyak 155 orang pengerajin dan batas kesalahan 10 persen, maka diperoleh sampel sebanyak 62 pengerajin pada industri kerajinan kulit di Kabupaten Badung.

Teknik analisis data yang digunakan dalam penelitian ini adalah metode analisis jalur (Path Analysis). Analisis jalur merupakan perluasan dari analisis regresi linier berganda, untuk menaksir hubungan kausalitas antar variabel ditunjukkan oleh anak panah. Uji sobel atau sering disebut uji pengaruh tidak langsung merupakan cara untuk menguji kekuatan tidak langsung untuk menguji kekuatan pengaruh tidak langsung antara variabel independent terhadap variabel dependen melaui intervening.

\section{HASIL DAN PEMBAHASAN}

Berdasarkan hasil penelitian dapat diketahui hubungan-hubungan antar variabel penelitian yang merupakan koefisien jalur dalam penelitian ini. Koefisien jalur dapat dibuat dalam bentuk diagram jalur (Suyana, 2012:156). Model tersebut juga dapat dinyatakan dalam persamaan struktural, yaitu:

Persamaan Struktural 1

$\mathrm{Y} 1=0,137 \mathrm{X}_{1}+1,001 \mathrm{X}_{2}+0,106 \mathrm{X}_{3}+0,035 \mathrm{X}_{4}+\mathrm{e}_{1}$ 
Persamaan Struktural 2

$\mathrm{Y} 2=0,104 \mathrm{X}_{1}+0,099 \mathrm{X}_{2}+0,206 \mathrm{X}_{3}+0,031 \mathrm{X}_{4}+0,907 \mathrm{Y}_{1}+\mathrm{e}_{2}$

Untuk mengetahui nilai $\mathrm{e}_{1}$ yang menunjukkan jumlah variance variabel produksi pengerajin pada industri kerajinan kulit di Kabupaten Badung yang tidak dijelaskan oleh tenaga kerja, modal, teknologi dan ketersediaan bahan baku, dihitung menggunakan rumus :

$e 1=\sqrt{1-R i^{2}}$

$e 1=\sqrt{1-0,827}=0,416$

Nilai $e_{2}$ yang menunjukkan variance variabel pendapatan pengerajin pada industri kerajinan kulit di Kabupaten Badung yang tidak dijelaskan oleh tenaga kerja, modal, teknologi, ketersediaan bahan baku, dan produksi maka dihitung menggunakan rumus :

$e 2=\sqrt{1-R i^{2}}$

$e 2=\sqrt{1-0,928}=0,268$

Untuk memeriksa validitas model, terdapat indikator untuk melakukan pemeriksaan, yaitu koefisien determinasi total hasilnya sebagai berikut :

$$
\begin{aligned}
R_{m}^{2} & =1-\left(P e_{1}\right)^{2}\left(P e_{2}\right)^{2} \\
& =1-(0,416)^{2}(0,268)^{2} \\
& =1-(0,173)(0,072) \\
& =0,988
\end{aligned}
$$


Berdasarkan hasil perhitungan koefisien determinasi total, maka diperoleh bahwa keragaman data yang dapat dijelaskan oleh model adalah sebesar 0,988 atau dengan kata lain informasi yang terkandung dalam data sebesar 98,8 persen dapat dijelaskan oleh model, sedangkan sisanya yaitu 1,2 persen dijelaskan oleh variabel lain yang tidak terdapat dalam model.

Berdasarkan hasil pengujian menunjukkan bahwa tenaga kerja berpengaruh positif dan signifikan terhadap produksi pengerajin pada industri kerajinan kulit di Kabupaten Badung. Hubungan signifikan tenaga kerja terhadap produksi sesuai dengan Teori Produksi yang mengemukakan bahwa tenaga kerja mempunyai pengaruh terhadap tingkat produksi. Seorang pengusaha dapat mengubah nilai Q (output) dengan jalan mengubah-ubah kuantitas dari salah satu input yang dipergunakan, dan mempertahankan input yang lain agar tetap konstan. Pada kondisi ini, output akan mencapai tingkat maksimum dan kemudian mulai menurun apabila lebih banyak input yang lain yang konstan (the law of diminishing returns).

Hasil penelitian ini didukung oleh penelitian yang dilakukan oleh Setiawati (2013) hasilnya bahwa tenaga kerja berpengaruh positif terhadap hasil produksi. Hal yang sama dikemukakan oleh Yuniartini (2013) yang dalam penelitiannya menyatakan bahwa tenaga kerja berpengaruh positif dan signifikan terhadap produksi. Tenaga kerja merupakan faktor produksi yang sangat penting dalam melakukan proses produksi dan bukan hanya dapat menyediakan lapangan pekerjaan tetapi juga memiliki kualitas yang terbaik (Fagbenle et al., 2012). 
Pengaruh signifikan tenaga terhadap produksi menunjukkan bahwa tenaga kerja merupakan variabel penting yang berpengaruh terhadap tingkat produksi yang dihasilkan perajin. Fenomena di lapangan menunjukkan bahwa masih ada kendala bagi tenaga kerja yaitu, hanya sedikit SDM yang bersedia menjadi perajin kulit. Oleh karena itu pemerintah perlu memberikan sosialisasi atau penyuluhan agar SDM atau perajin mampu mengembangkan strategi produksi dan pemasaran yang lebih baik. Hasil penelitian ini juga didukung oleh hasil wawancara dengan salah satu perajin kulit (sepatu) yaitu Arifin yang merupakan salah satu perajin kulit di Jalan Raya Legian Kuta, Badung pada 30 September 2018 dan menyatakan bahwa:

"Penggunaan tenaga kerja dapat meningkatkan produksi yang dihasilkan. Tenaga kerja mampu memberikan kontribusi yang tinggi terhadap kuantitas produk yang dihasilkan. Oleh karena itu salah satu strategi yang biasanya dilakukan adalah dengan pengoptimalan jam kerja”.

Pada hasil pengujian menujukkan modal berpengaruh positif dan signifikan terhadap produksi pengerajin pada industri kerajinan kulit di Kabupaten Badung. Hasil penelitian ini sesuai dengan teori Produksi yang merupakan suatu fungsi produksi yang digunakan untuk hasil dari dua variabel masukan input dalam proses produksi. Teori produksi memiliki dua peranan pada teori harga relatif antara lain menyediakan sebuah landasan bagi analisis hubungan antara biaya dan volume output dan menjadi sebuah landasan bagi teori permintaan perusahaan akan faktor-faktor produksi (Cho, 1999). 
Hasil penelitian ini sesuai dengan hasil penelitian Yuniartini (2013) menyatakan bahwa modal berpengaruh positif dan signifikan terhadap produksi. Hal ini menunjukkan bahwa semakin banyak modal yang dimiliki oleh seseorang maka akan semakin tinggi peluang untuk menghasilkan output yang lebih banyak. Modal merupakan semua bentuk kekayaan yang dapat digunakan langsung maupun tidak langsung dalam proses produksi untuk menambah output (Hentiani, 2011).

Hasil dari penelitian terdahulu dari Yuniartini (2013) dan Hentiani (2011) di atas menguatkan pendapat bahwa modal sangat dibutuhkan untuk proses produksi dan selama opersional kegiatan, dimana dengan adanya modal maka perajin dapat membeli bahan baku yang lebih berkulitas dan dapat melakukan perawatan yang lebih baik dalam upaya peningkatan produksi kerajinan kulit. Perajin yang memiliki modal yang lebih besar akan lebih mampu memproduksi kerajianna kulit yang lebih banyak dan lebih berkualitas.

Pada hasil pengujian menujukkan penggunaan teknologi modern menghasilkan produksi yang lebih tinggi daripada teknologi tradisional. Teknologi sebagai suatu alat bantu dapat dimanfaatkan dalam proses produksi, sehingga upaya untuk meningkatkan penjualan dapat secara maksimal dilakukan dan pendapatan usaha akan mengalami peningkatan. Bantuan teknologi berupa mesin dapat mempercepat dan memudahkan proses produksi yang dilakukan. Apabila jumlah bahan baku meningkat dan dalam produksinya didukung oleh pemanfaatan teknologi berupa mesin yang memadai akan mendorong peningkatan jumlah output dan pendapatan usaha. Dengan bertambahnya jumlah output dari 
proses produksi, maka pendapatan yang akan dipeoleh perusahaan juga akan meningkat (Ilyas, 2011).

Pada hasil pengujian menujukkan ketersediaan bahan baku yang lancar menghasilkan produksi yang lebih tinggi daripada yang kurang lancar. Hubungan signifikan bahan baku terhadap produksi sesuai dengan pernyataan Skinnerand (1990), yang menyatakan bahan baku merupakan bagian yang integral dari produk yang di hasilkan oleh suatu perusahaan. Hasil penelitian ini di dukung penelitian Setiawan (2012) yang menyatakan bahan baku mempunyai pengaruh tinggi terhadap produksi, karena apabila bahan baku sulit didapatkan maka produsen akan menghentikan proses produksi begitu juga sebaliknya jika bahan baku mudah di dapatkan maka proses produksi akan berjalan dengan lancar dan produksi akan meningkat. Bahan baku merupakan faktor produksi dibutuhkan dalam proses produksi. Persediaan bahan baku di dalam perusahaan merupakan hal yang sangat penting untuk dikendalikan dengan baik, sehingga perusahaan dapat menghasilkan produksi yang optimal.

Berdasarkan analisis diatas dapat dikatakan bahwa semakin banyak bahan baku maka produksi semakin meningkat pula. Ini didukung oleh (Setiawan, 2012) bahan baku mempunyai pengaruh tinggi terhadap produksi, karena apabila bahan baku sulit didapatkan maka produsen akan menghentikan proses produksi begitu juga sebaliknya jika bahan baku mudah di dapatkan maka proses produksi akan berjalan dengan lancar dan produksi akan meningkat. Fenomena yang terjadi di lapangan pada saat observasi menunjukkan bahwa perajin kulit di Kabupaten Badung menujukkan bahwa harga bahan baku untuk pembuatan kerajianna kulit 
cukup mahal, dimana bahan baku yang berkualitas akan menghasilkan produk yang berkualitas.

Pada hasil pengujian hipotesis menujukkan tenaga kerja berpengaruh positif dan signifikan terhadap pendapatan pengerajin pada industri kerajinan kulit di Kabupaten Badung. Hasil penelitian ini sesuai dengan pernyataan Sukirno (2015:12), yang menyatakan tenaga kerja merupakan faktor penting yang mempengaruhi pendapatan. Tenaga kerja merupakan faktor penggerak faktor input yang lain, tanpa adanya tenaga kerja maka faktor produksi lain tidak akan berarti (Wiyasa, 2017). Dengan meningkatnya produktifitas tenaga kerja akan mendorong peningkatan produksi sehingga pendapatan pun akan ikut meningkat. Hal ini sesuai dengan hasil penelitian Sumarsono (2013) yang menyatakan bahwa jumlah tenaga kerja berpengaruh positif terhadap pendapatan. Artinya, semakin banyak tenaga kerja yang digunakan maka semakin besar peluang untuk memperoleh pendapatan yang lebih tinggi.

Hasil penelitian ini juga di dukung oleh Yuniartini (2013) yang menyatakan bahwa tenaga kerja berpengaruh positif dan signifikan terhadap pendapatan. Hasil penelitian Putra (2015) menyatakan bahwa tenaga kerja berpengaruh positif dan signifikan terhadap pendapatan. Artinya ketika tenaga kerja yang digunakan meningkat maka permintaan yang dapat dipenuhi semakin besar dan pendapatan yang diterima perusahaan juga akan meningkat.

Pada hasil pengujian hipotesis menujukkan modal berpengaruh positif dan signifikan terhadap pendapatan pengerajin pada industri kerajinan kulit di 
Kabupaten Badung. Hubungan signifikan modal terhadap pendapatan sesuai dengan teori biaya yang dijabarkan Noor (2007), yang menyatakan biaya merupakan faktor penting dalam mendapatkan formulasi input (biaya) yang paling efisien untuk menghasilkan output (barang dan jasa) tertentu. Biaya dikeluarkan untuk menghasilkan manfaat dalam bentuk pendapatan di masa kini maupun di masa datang. Semakin minimum biaya yang dikeluarkan maka semakin baik dampaknya terhadap pendapatan yang dihasilkan. Bisnis yang dibangun tidak akan berkembang tanpa di dukung dengan adanya modal. Modal dapat dikatakan menjadi jantungnya bisnis yang dibangun tersebut (Firdausa, 2012). Maka dari itu, adanya modal akan mempengaruhi pendapatan yang akan diterima.

Hal ini juga sejalan dengan hasil penelitian Yanutya (2013), menyatakan bahwa secara parsial modal berpengaruh positif dan signifikan terhadap terhadap pendapatan. Hal ini mengindikasikan bahwa semakin besar modal yang dimiliki maka akan semakin besar pendapatan yang akan diperoleh. Hal ini juga sejalan dengan hasil penelitian Adhiatma (2014), yang menyatakan bahwa modal secara parsial memiliki pengaruh yang signifikan terhadap pendapatan. Menurut hasil wawancara dengan Budiman yang merupakan salah satu perajin kulit di Jalan Pelita Tuban, Badung pada 30 September 2018 berpendapat:

"Modal merupakan faktor penentu tingkat pendapatan. Jika modal tinggi dan dengan diimbangi tingginya permintaan konsumen maka pendapatan akan maksimum. Semakin banyak modal yang dimiliki maka akan semakin besar peluang perajin untuk memperoleh pendapatan yang lebih tinggi karena semakin produksi yang mampu dihasilkan". 
Pada hasil pengujian hipotesis menujukkan penggunaan teknologi modern menghasilkan pendapatan yang lebih tinggi daripada teknologi tradisional. Teknologi sebagai suatu alat bantu dapat dimanfaatkan dalam proses produksi, sehingga upaya untuk meningkatkan penjualan dapat secara maksimal dilakukan dan pendapatan usaha akan mengalami peningkatan. Bantuan teknologi berupa mesin dapat mempercepat dan memudahkan proses produksi yang dilakukan. Apabila jumlah bahan baku meningkat dan dalam produksinya didukung oleh pemanfaatan teknologi berupa mesin yang memadai akan mendorong peningkatan jumlah output dan pendapatan usaha. Dengan bertambahnya jumlah output dari proses produksi, maka pendapatan yang akan dipeoleh perusahaan juga akan meningkat (Ilyas, 2011). Menurut hasil wawancara dengan Galih yang merupakan salah satu perajin kulit di Jalan Patih Jelantik, Legian Kelod, Kuta, Kabupaten Badung pada 30 September 2018 berpendapat:

"Penggunaan teknologi merupakan salah satu faktor yang akan mempengaruhi produksi dan juga akan berdapak pada peningaktan pendapatan. Penggunaan teknologi modern memberikan peluang yang besar bagi perajin untuk memperoleh pendapatan yang lebih tinggi karena semakin produksi yang mampu dihasilkan”.

Pada hasil pengujian hipotesis menujukkan Ketersediaan bahan baku yang lancar menghasilkan pendapatan yang lebih tinggi daripada yang kurang lancar. Bahan baku disebut juga bahan dasar yang dipergunakan untuk memproduksi suatu barang. Bahan baku merupakan bagian yang integral dari produk yang di 
hasilkan oleh suatu perusahaan (Skinnerand, 1990). Setiap perusahaan yang menyelenggarakan kegiatan produksi akan memerlukan persediaan bahan baku. Semakin besar jumlah bahan baku yang dimiliki, maka semakin besar pula kemungkinan jumlah produk yang di hasilkan sehingga kemungkinan pendapatan yang diterima semakin besar dari hasil penjualan produksi.

Bahan baku juga merupakan faktor penting yang mempengaruhi pendapatan. Semakin besar jumlah bahan baku yang dimiliki, maka semakin besar pula kemungkinan jumlah produk yang dihasilkan, sehingga kemungkinan pendapatan yang diterima semakin besar dari hasil penjualan produksinya. Bahan baku merupakan jumlah bahan yang diperlukan untuk melaksanakan proses produksi dalam jangka waktu tertentu (Siswanta, 2011).

Berdasarkan hasil analisis di atas, variabel bahan baku berpengaruh langsung dan signifikan terhadap pendapatan. Menurut Reiner Kummel (2002), bahan baku merupakan faktor produksi yang dibutuhkan dalam setiap proses produksi. Bahan baku merupakan sarana dari industri agar bisa melakukan kegiatannya. Tersedianya bahan baku dalam jumlah yang cukup, berkesinambungan dengan harga yang dapat dijangkau akan memperlancar produksi yang pada akhirnya akan meningkatkan produksi serta meningkatkan jumlah pendapatan usaha yang diperoleh. Semakin besar jumlah bahan baku yang dimiliki, maka semakin besar pula kemungkinan jumlah produk yang dihasilkan, sehingga kemungkinan pendapatan yang diterima semakin besar dari hasil penjualan produksinya. Salah satu cara yang dapat dilakukan adalah dengan memperluas relasi atau jaringan pemasok bahan baku, tidak hanya dari Bali tapi 
juga dari luar Bali. Menurut Bayu Ardana yang merupakan salah satu perajin kulit (sepatu) di Kabupaten Badung saat wawancara mendalam berpendapat:

"Ketersediaan bahan baku adalah akan mempengaruhi produksi dan pendapatan. Kelancaran ketersediaan bahan baku akan memberikan peluang yang besar bagi perajin untuk memperoleh pendapatan yang lebih tinggi karena semakin produksi yang mampu dihasilkan”.

Pada hasil pengujian hipotesis menujukkan produksi berpengaruh positif dan signifikan terhadap pendapatan pengerajin pada industri kerajinan kulit di Kabupaten Badung. Hasil penelitian ini sejalan dengan teori produksi. Fungsi produksi merupakan suatu fungsi yang menunjukkan hubungan matematik antara input yang digunakan untuk menghasilkan suatu tingkat output tertentu (Sukirno, 2012). Tingkat produksi akan mempengaruhi tingkat pendapatan yang diperoleh oleh seorang pengusaha (Moiseeva, 2009). Ketika produksi yang dihasilkan menurun maka pendapatan yang diterima perajin akan mengalami penurunan. Hal ini karena produksi adalah salah satu faktor yang mempengaruhi besar kecilnya pendapatan.

Hasil penelitian ini di dukung penelitian dari Godby (2015), yang menyatakan bahwa tingkat produksi akan berbanding lurus dengan tingkat pendapatan yang diperoleh seseorang. Menurut Limi (2013), menunjukan bahwa terdapat hubungan yang positif antara jumlah produksi terhadap pendapatan. Artinya, semakin tinggi jumlah produksi yang dihasilkan maka akan semakin tinggi pendapatan yang diperoleh. Hal ini juga sesuai dengan penelitian Penelitian 
ini juga sesuai dengan studi empiris Tumoka (2013), yang menyatakan bahwa jumlah produksi berpengaruh positif dan signifikan terhadap pendapatan.

Berdasarkan hasil analisis, apabila terjadi kenaikan produksi secara otomatis juga akan meningkatkan pendapatan perajin kulit di Kabupaten Badung. Diperkuat oleh pendapat Utari (2014) semakin banyak seorang pengerajin menghasilkan barang produksi maka pendapatan yang diperoleh akan semakin banyak. Banyaknya jumlah produk yang dihasilkan akan mampu meningkatkan keuntungan perusahaan. Hal ini tentu berimbas pada pendapatan yang diterima oleh perajin. Perajin akan semakin termotivasi untuk menambah produktivitas kerjanya baik dari segi kualitas maupun kuantitas. Lebih lanjut hasil wawancara dengan Bayu Ardana yang merupakan salah satu perajin kulit (sepatu) di Jalan Kunti II, Seminyak, Kuta, Badung pada 30 September 2018 menyatakan bahwa : "Dengan adanya peningkatn produksi dan penambahan permintaan pasar maka tentunya pendapatan akan semakin meningkat. Hal ini karena dengan adanya peningkatan produksi maka akan semakin banyak peluang untuk memasarkan produk. Meskipun dengan adanya peningkatan produksi tidak serta merta dapat meningkatkan pendapatan apabila tidak terjadi peningkatan permintaan pasar".

Nilai $Z$ hitung sebesar $1,772<1,96$ artinya tidak terdapat pengaruh tidak langsung tenaga kerja terhadap pendapatan melalui produksi pengerajin pada industri kerajinan kulit di Kabupaten Badung.

Nilai $8,071>1,96$ artinya produksi sebagai variabel yang memediasi secara signifikan modal terhadap pendapatan pengerajin pada industri kerajinan 
kulit di Kabupaten Badung. Hal ini menunjukkan bahwa ketika terjadi penambahan modal maka tidak serta merta dapat langsung berpengaruh terhadap pendapatan apabila tidak ada peningkatan produksi.

Nilai Z hitung sebesar 7,190 > 1,96 artinya produksi sebagai variabel yang memediasi secara signifikan teknologi terhadap pendapatan pengerajin pada industri kerajinan kulit di Kabupaten Badung.

Nilai Z hitung sebesar 4,688 > 1,96 artinya produksi sebagai variabel yang memediasi secara signifikan pengaruh ketersediaan bahan baku terhadap pendapatan pengerajin pada industri kerajinan kulit di Kabupaten Badung.

\section{SIMPULAN DAN SARAN}

Berdasarkan hasil analisis dapat disimpulkan bahwa tenaga kerja dan modal secara langsung berpengaruh positif dan signifikan terhadap produksi pengerajin pada industri kerajinan kulit di Kabupaten Badung. Penggunaan teknologi modern menghasilkan produksi yang lebih tinggi daripada teknologi tradisional. Ketersediaan bahan baku yang lancar menghasilkan produksi yang lebih tinggi daripada yang kurang lancar. Tenaga kerja, modal dan produksi secara langsung berpengaruh positif dan signifikan terhadap pendapatan pengerajin pada industri kerajinan kulit di Kabupaten Badung. Penggunaan teknologi modern menghasilkan pendapatan yang lebih tinggi daripada teknologi tradisional. Ketersediaan bahan baku yang lancar menghasilkan pendapatan yang lebih tinggi daripada yang kurang lancar. Terdapat pengaruh tidak langsung modal, teknologi dan ketersediaan bahan baku terhadap pendapatan melalui produksi sedangkan 
tidak terdapat pengaruh tidak langsung tenaga kerja terhadap pendapatan melalui produksi pengerajin pada industri kerajinan kulit di Kabupaten Badung.

Saran yang dapat diberikan adalah untuk meningkatkan pendapatan dapat dilakukan dengan cara memberikan bantuan modal dari pemerintah maupun dari lembaga keuangan bank atau lembaga keuangan bukan bank mengingat usaha kerajinan kulit memiliki potensi yang cukup besar dari segi pendapatan sehingga akan dapat lebih menyejahterakan masyarakat. Melalui bantuan modal, maka pengusaha dapat meningkatkan produksinya sehingga tenaga kerja yang dibutuhkan juga akan meningkat untuk dapat meningkatkan pendapatan usaha Untuk meningkatkan faktor tenaga kerja sangat mempengaruhi pendapatan, maka sebaiknya perajin lebih mengoptimalkan penggunaan jam kerja, karena dengan demikian tingkat produksi yang dihasilkan akan mengalami peningkatan.

Bagi pengerajin sebaiknya memanfaatkan teknologi modern sehingga lebih efektif dan efisien dalam proses produksi, salah satunya dengan menggunakan mesin atau alat-alat canggih dalam proses produksi. Kelancaran bahan baku mempengaruhi tingkat produksi dan pendapatan pengerajin kulit di Kabupaten Badung. Salah satu cara yang dapat dilakukan adalah dengan memperluas relasi atau jaringan pemasok bahan baku, tidak hanya dari Bali tapi juga dari luar Bali.

\section{REFERENSI}

Adhiatma, Alfian Arif. 2015. Pengaruh Modal Awal, Lama Usaha, Dan Jam Kerja Terhadap Pendapatan Pedagang Kayu Glondong Di Kelurahan Karang Kebagusan Kabupaten Jepara. Tugas Akhir Semester. Universitas Dian Nuswantoro Semarang. 
Agyapong, 2010. Micro, Small and Medium Enterprises' Activities, Income Level and Poverty Reduction in Ghana - A Synthesis Of Related Literature. International Journal of Bussiness and Management. Vol.5 No.12.

Allo, Albertus Girik. Liberalisasi Keuangan dan Pembangunan Ekonomi: Belajar dari Krisis Ekonomi Indonesia. Jurnal Ekonomi Kuantitatif Terapan, [S.1.], jan. 2017. ISSN 2303-0186. Available at: <https://ojs.unud.ac.id/index.php/jekt/article/view/27429>. Date accessed: 18 okt. 2017.

Ariessi, Nian Elly ., dan Made Suyana Utama. 2017. Pengaruh Modal, Tenaga Kerja Dan Modal Sosial Terhadap Produktivitas Petani Di Kecamatan Sukawati Kabupaten Gianyar. Piramida. 13(2): h: 97-107.

Artana Yasa, I Komang Oka; ARKA, Sudarsana. Pengaruh Pertumbuhan Ekonomi Dan Disparitas Pendapatan Antardaerah Terhadap Kesejahteraan Masyarakat Provinsi Bali. Jurnal Ekonomi Kuantitatif Terapan, [S.1.], nov. 2015. ISSN 2303-0186. Available at: <https://ojs.unud.ac.id/index.php/jekt/article/view/16494>. Date accessed: 18 okt. 2017.

Asmie, Poniwati. 2008. Analisis Faktor-faktor Yang Mempengaruhi Tingkat Pendapatan Pedagang Pasar Tradisional Di Kota Yogyakarta. Jurnal Ilmiah. Universitas Gajah Mada Yogyakarata.

Catherine, Ikeocha Chibuogwu. 2012. The Impact Of Research Findings In The Performance Of The Manufacturing Industry A Case Study Of Nigerian Breweries Plc. Research Of Department Of Management . Faculty Of Business Administration University Of Nigeria Enugu Campus.

Cho, Dongsae. 1999. The Impact Of A Price Cut On Net Income And Profit Margin. Journal of Financial and Strategic Decisions. 12(2): pp: 1-12.

Fagbenle, Olabosipo I,, Lawal Philip O,, and Omuh, Igartius O. 2012. The Influence Of Training On Bricklayers Productivity In Nigeria. International Journal of Managemen Sciences and Business Research. 1 (7).

Firdausa, Rosetyadi Artistyan. 2013. Pengaruh Modal Awal, Lama Usaha, Dan Jam Operasional Terhadap Pendapatan Pedagang Kios Di Pasar Bintoro Demak. Diponegoro Journal Of Economics. Vol. 2, No. 1, pp: 1-6.

Ginting, Elsa Astarina. 2008. Analisis Pengaruh Kredit Perbankan, LamaUsaha dan Tingkat PendidikanTterhadap Omset Pengusaha KecilRotan di 
Kecamatan Medan Barat, Medan. Jurnal Ilmiah. Fakultas EkonomiUniversitas Sumatra Utara, Medan.

Godby, Robert., Roger Coupal., David Taylor and Tim Considine. 2015. The Impact of the Coal Economy on Wyoming. The Journal of Economic and Fublic Policy. 2(2): pp: 234-254.

Hae-Young Lee, Jongsung Kim and Beom Cheol Cin. 2013. Empirical Analysis on the Determinants of Income Inequality in Korea. International Journal of Advanced Science and Technology. 53, pp: 95-110.

Hart, Keith. 1971. Small-Scale Entrepeneur in Ghana and Development Planning. The Journal Of Development Studies, 6 (4), pp: 104 -119.

Idayanti, Fitria., dan Putu Martini Dewi. 2015. Analisis Faktor-Faktor Produksi Domestik Yang Mempengaruhi Ekspor Kerajinan Kayu di Kecamatan Ubud Kabupaten Gianyar. E-Jurnal EP Unud, 5(1): h: 195-215.

Ilyas, Yaslis. 2011. Kinerja, Teori, Penilaian dan Pelatihan. Jakarta: BP FKUM UI.

Istanti, Yeni.., dan Ni Luh Karmini. 2016. Pengaruh Bahan Baku, Tenaga Kerja dan Investasi Terhadap Produksi Seta Ekspor Keramik di Kabupaten Tabanan. E-Jurnal EP Unud, 5(2): h: 276-297.

Juan Zhao, 2008. Research on the Financing of Small and Medium Enterprises. International Journal of Business an Management. Vol.3, no.11 november 2008.

Kurniawan, Jarot. Dilema Pendidikan dan Pendapatan di Kabupaten Grobogan. Jurnal Ekonomi Kuantitatif Terapan, [S.1.], july 2016. ISSN 2303-0186. Available

at: <https://ojs.unud.ac.id/index.php/jekt/article/view/22756>. Date accessed: 18 okt. 2017.

Limi, Muhammad Anwar,2013, Analisis Jalur Pengaruh Faktor Produks iterhadap Produksi dan Pendapatan Usahatani Kacang tanah di Kecamatan Lembo Kabupaten Konawe Utara, AGRIPLUS, Volume 23 Nomor : 02 Mei 2013, pp. 124-132.

Moiseeva, Maria. 2009. The Dynamics of Productions Outputs. Journal of International Research Publication: Economy and Business. 4: pp: 186207.

Mutiara Ayu. 2010. Analisis Bahan Baku, Bahan Bakar dan Tenaga Kerja Terhadap Produksi Tempe di Kota Semarang (Studi KasusKelurahan 
Krobokan). Jurnal Ilmiah. Program S1 Fakultas Ekonomi Universitas Dipenogoro Semarang.

Ningsih, Ni Made Cahya; Indrajaya, I Gst. Bagus. Pengaruh Modal Dan Tingkat Upah Terhadap Nilai Produksi Serta Penyerapan Tenaga Kerja Pada Industri Kerajinan Perak. Jurnal Ekonomi Kuantitatif Terapan, [S.1.], nov. 2015. ISSN 2303-0186. Available at: <https://ojs.unud.ac.id/index.php/jekt/article/view/16499>. Date accessed: 18 okt. 2017.

Noor, H. F. 2007. Ekonomi Manajerial. Jakarta: Raja Grafindo Persada.

Parinduri, Rasyad A. 2016. Family Hardship and The Growth Of Micro And Small Firms In Indonesia. Bulletin of Indonesian Economic Studies. 50(1), pp: 53-73.

Pieere Van Der Eng.2009. Capital Information and Capital Stock In Indonesia 1950-2008. Bulletin of Indonesia Economic Studies. 345-371.

Prastyo, Didik., dan I Nengah Kartika. 2017. Analisis Faktor-Faktor Yang Mempengaruhi Produksi Ayam Broiler Di Kecamatan Marga, Kabupaten Tabanan. Piramida. 13(2): h: 77-86.

Putra, I Putu Danendra dan I Wayan Sudirman. 2015. Pengaruh Modal dan Tenaga Kerja Terhadap Pendapatan Dengan Lama Usaha Sebagai Variabel Moderating. E-Jurnal EP Unud. 4(9), h: 1048-1193.

Putri, Ni Made Dwi Maharani; Jember, I Made. Pengaruh Modal Sendiri dan Lokasi Usaha Terhadap Pendapatan Usaha Mikro Kecil Menengah (UMKM) di Kabupaten Tabanan (Modal Pinjaman sebagai Variabel Intervening). Jurnal Ekonomi Kuantitatif Terapan, [S.1.], jan. 2017. ISSN 2303-0186. Available at: <https://ojs.unud.ac.id/index.php/jekt/article/view/27432>. Date accessed: 18 okt. 2017.

Reiner Kummel., Julian Henn and Dietmar Lindenberger 2002. Capital, Labor, energy and creativity: modelling innovation diffusion. Journal Structural Change and Economic Dynamics. 13(2): h: 415-433.

Revathy, S. and V.Santhi. 2016. Impact Of Capital Structure On Profitability Of Manufacturing Companies In India. International Journal of Advanced Engineering Technology. 7(1), pp: 24-28.

Setiawati, Devia. 2013. Faktor-Faktor Yang Mepengaruhi Hasil Produksi Tempe pada Sentra Industri Tempe Di Kecamatan Sukorejo Kabupaten Kendal. Jurnal Jurusan Ekonomi Pembangunan, Fakultas Ekonomi Universitas 
Negeri Semarang. (Online) (Journal.unnes.ac.id/sju/index.php/edaj, di akses pada tanggal 23 November 2016).

Skinnerand, Steven J. 1990. Customer participation in service production and delivery. Journal of Retailing. 66(3): h: 57-70.

Sukirno, Sadono. 2015. Makro Ekonomi Modern. Jakarta: PT. Raja Grafindo Persada.

-----. 2012. Makro Ekonomi Modern. Jakarta: PT. Raja Grafindo Persada.

Sumarsono, Hadi. 2013. Faktor-faktor Yang Mempengaruhi Intensi Wirausaha Mahasiswa. Universitas Muhammadiyah Ponorogo. Jurnal Vol.11 No.2, h: 1-23.

Suyana Utama. 2012. Aplikasi Analisis Kuantitatif (Edisi Keenam). Diktat Kuliah. Denpasar: Fakultas Ekonomi dan Bisnis Universitas Udayana.

Todaro, M.P. 2006. Pembangunan Ekonomi di Dunia Ketiga. Jakarta: Penerbit Erlangga.

Tumoka, Nova. 2013. Analisis Pendapatan Usaha Tani Tomat Di Kecamatan Kawangkoan Barat Kabupaten Minahasa. Jurnal Emba. 1(3): h: 345-354.

Utari, Tri. 2014. Pengaruh Modal, Tingkat Pendidikan dan Teknologi Terhadap Pendapatan Usaha Mikro Kecil dan Menengah (UMKM) Di Kawasan Imam Bonjol Denpasar Barat. E-Jurnal Ekonomi Pembangunan Universitas Udayana. 3(12): 576-585.

Wiyasa, Ida Bagus Windu., dan Made Heny Urmila Dewi. 2017. Faktor-Faktor Yang Mempengaruhi Pendapatan Melalui Curahan Jam Kerja Ibu Rumah Tangga Pengrajin Bambu Di Kabupaten Bangli. Piramida. 13(1): h: 27-36.

Woo, Wing Thye and Hong, Chang. 2010. Indonesia's economic performance in comparative perspective and a new policy framework for 2049', Bulletin of Indonesian Economic Studies. 46(1): pp: 33-64.

Yuniartini, Ni Putu Sri. 2013. Pengaruh Modal, Tenaga Kerja dan Tekonologi terhadap Produksi Industri Kerajinan Ukiran Kayu di Kecamatan Ubud. EJurnal EP Unud, 2(2), h: 95-101. 